\title{
Organizational Design and Rules in Rastin Profit and Loss Sharing Banking
}

\author{
Bijan Bidabad ${ }^{\mathrm{I}}$ \\ Roohollah Mohammadi ${ }^{2}$ \\ Mahshid Sherafati ${ }^{3}$
}

\begin{abstract}
Purpose: This paper aims to explain the organizational structure of Rastin Profit and Loss Sharing (PLS) Banking. Rastin Banking is a full Islamic Banking System with all necessary parts for banking operations that can be installed in conventional and Islamic banks both.
\end{abstract}

Design: Rastin Banking complies with the nature of the financial intermediary activity (the partnership of depositor in the yields of the fund receiver via the bank). To fulfill this goal, particular organizational structure, accompanying with instruments and workflow are defined.

Findings: To handle Rastin Banking, particular theoretical and operational regulatory frameworks should be defined to fulfill the participation operations. In this paper, we will have a look at the necessary organizational structure to setup Rastin Banking.

Research limitations: This plan was formed and tested in Bank Melli Iran in order to propose a model for other banks as well.

Practical implications: In this system, the investment return of the participation is distributed to the parties of the financial partnership (depositor, entrepreneur, and bank), and it is done by eliminating fixed interest rate, and it is based on the real economy profit (return) of the activity.

Social implications: Rastin Banking can lead to important positive effects on growth and economic welfare through money and capital markets. Interest rate as an essential factor in conventional banking is not usable in Islamic banking and other similar institutions that work based on partnership, such as mutual funds and saving and loan associations.

Originality/value: Approach of this system is entirely different from conventional banking. In addition to removing usury in banking activities, Rastin Banking uses the best practical ethic finance to creating safe and public confidence environment for banking operations.

Article Type: Technical paper

Keywords: Organization, Rastin Banking, Profit and Loss Sharing (PLS), Rastin Profit and Loss Sharing (PLS) Banking, Islamic Banking, Musharakah.

\section{Introduction}

As it is expressed, an organization is a social entity that is goal-directed, is designed as deliberately structured and coordinated activity system and is linked to the external environment. ${ }^{4}$ An organization is made up of people and their relationships with one another. Manager/s deliberately structure and coordinate organizational resources to achieve the purpose of the organization.

Organizations are facing globalization (environment for the companies becomes extremely complex and competitive.); social and

I (B.A., M.Sc., Ph.D., Post-Doc.) Professor of Economics and Chief Islamic Banking Advisior, Bank Melli Iran. bijan@bidabad.com, Bidabad@yahoo.com http://www.bidabad.com

${ }^{2}$ CEO at Novin-Pajoohan Research Institute, Tehran, Iran.r_mohamadi58@yahoo.com

${ }^{3}$ MBA Department, Management Faculty, Multimedia University, Malaysia, mahshidsherafati@gmail.com

${ }^{4}$ Daft, Richard L. (20I5) Organization Theory and Design I2 ${ }^{\text {th }}$ Edition, South-Western College Publisher. 
ethics responsibility (the managers are facing pressure to hold the organization and employees to observe ethical and professional standards); speed of responsiveness (quick respond to external changes and internal crises, or deformations of the clients' taste and expectations); digital workplace (elimination of the middleman due to Information and Communication Technologies (ICT) development); and supporting people diversity.

Regarding the design of an organization, the structural dimensions of formalization (reliance upon compiled instructions), specialization (the degree of splitting jobs in the organization), hierarchy (who should report to whom), degrees of centralization/decentralisation, professionalism (the level of formal education and professional training of employees), personnel ratios (the ratio of the number of employees in a specific office/department to the total employees number) are to be considered apriori.

In Rastin Banking, regardless of whether the bank is a state or a private entity, the basis for determining the interest rate is the return rate of the real economy. The bank, as an intermediary of funds, receives the wage as the attorney or agent. Afterward, all the returns obtained from the investment, whether profit or loss, will be transferred to the owners of financial resources (i.e., depositors). Accordingly, the agent banks, based on participatory contracts, can invest the investment deposits in the intended project(s), based on the general/special power of attorney and according to the depositor's recognition (in the products of the first or the second types) or the bank's recognition (in the products of the third type) and will finally distribute the returns of investment among the depositors (financial resources owners). The real profit or loss will be distributed according to the detailed instructions, the respective criteria, and the mutual agreement between the contracting parties. In this regard, in order to complete its financial intermediation, the bank will firstly deduct its wage and then will transfer the benefits obtained from the investment to the depositors. ${ }^{5}$

In Rastin Banking, all the aspects of the implementation of the profit and loss sharing (PLS) banking have been well considered. In this paper, one of the main instances, which is the operating organization is to be explained.

\section{Organization Theories, Structure, and Design}

Many researchers have discussed the organizational theory that fits the needs best. These approaches include bureaucracy, scientific management, division of labor, and modernization.

In the identification of the principle components of an ideal bureaucracy, Weber states the following characteristics ${ }^{6}$ :

- Official jurisdiction is arranged by a set of implemented rules or laws.

- Existence of an office hierarchy.

- The management is done based on written rules.

- Training and specialisation is a management requirement.

- The requirement of the full working capacity of individuals.

- The rules are to be learned.

- Implemented bureaucracy could provide accountability, control, responsibility, and consistency.

- Though the classical perspective is looking for more efficiency, it is often a critic of ignoring human differentiation.

By scientific management Taylor asserts how output can be maximized with minimum input through goal specification (the specific for resource allocation) and formalization (standardization of organizational behavior): ${ }^{7}$

- Dividing work among managers and personnel

- Providing a performance- incentive system

- Scientific training of the personnel

- Developing the scientific individual's responsibilities

- On time and time-efficient working

The division of labor emphasizes on the specialization of each worker role due to occupational specialty, not changing the tasks,

\footnotetext{
${ }^{5}$ Bidabad, Bijan. (20I4). New Operational Islamic Banking System, Volume One, Theoretical Foundations, LAP Lambert Academic Publishing, OmniScriptum GmbH \& Co. KG, ISBN: 978-3-659-54463-7.

Bidabad, Bijan. (20I4). New Operational Islamic Banking System, Volume Two, Applicational Issues, LAP Lambert Academic Publishing, OmniScriptum GmbH \& Co. KG, ISBN: 978-3-659-552I0-6.

${ }^{6}$ Weber, Max. Economy and Society: An Outline of Interpretive Sociology (2 Volume Set). University of California Press.

${ }^{7}$ Taylor, Frederick Winslow (I9II). The principles of scientific management. New York: Harper Brothers.
} 
and machines taking the place of human labor as Adam Smith states as well as matching and similarity of human capital and physical capital as a major base for an increase in productivity.

Modernization theory deals with the cessation of traditional methods in order to pursue modern, efficient organizational methods in the formation of industrialism. ${ }^{9}$ Modernization theory took place about the diffusion of technological innovations, more qualified labors, and methods impersonality. The goal of modern organizations to maximize efficiency is reachable through scientific innovations and discoveries, and the existing organizations that adopt non-efficient solutions are eliminated. The organization is to generate maximum profit, through the use of mass media communications, technological innovations, and social changes in order to efficiently allocate the resources. ${ }^{\text {I0 }}$

For designing an organization, the five essential parts of the technical core, top management, middle management, administrative support, and technical support should be sketched for the adequate performance of the subsystem's functions. Organizational dimensions consist of structural dimensions and contextual aspects. The former describes the internal characteristics of the organization, as formalization (the amount of written rules, instructions and documentation etc.), specialization (the degree of subdivided tasks), authority hierarchy (who reports to whom), centralization (the hierarchical level that make a decision), professionalism (formal education and training of personnel) and staff ratios (deployment of the staff to various functions/departments). Contextual dimensions characterize the whole organization and the environment including the size (number of people), technology (instruments, tools, techniques and the actions used for transforming inputs to outputs), environment (outside the organization), goals and strategy (purpose and competitive methods) culture (underlying beliefs, values, norms and understandings shared by the personnel). ${ }^{\mathrm{II}}$

The key components of organizational structure are formal reporting relationships and task responsibilities, including the hierarchy levels, and the grouping of individuals into different departments and of departments into the organization and the systems to ensure effective communication and coordination and integration of efforts across the departments and among the personnel. Moreover, the organization should be designed in a way to provide both vertical and horizontal information transfer and flows to accomplish the organization's overall goals. The organization needs sufficient instructions and standards for all processes and procedures. ${ }^{\mathrm{I2}}$

All these considerations were taken into account to design the organizational structure for Rastin Profit and Loss Sharing (PLS) Banking

\section{Rastin Profit and Loss Sharing (PLS) Banking}

Rastin Profit and Loss Sharing (PLS) Banking has been designed based on three banking products/services as participation in a particular project; participation in a package of several projects; and participation in the profit and loss of the bank/a branch that executes Rastin Profit and Loss Sharing (PLS) project. The bank will prepare a Joalah (wage) contract with the depositor and according to the depositor's decision on one of the three mentioned products prepares his/her participation in the outcome (profit or loss) of the entrepreneur's project. On the other side, based on civil participation contract, the bank will deal with the entrepreneur and by receiving Jo'alah fee or wage, will allocate the deposit resources to investment project of the entrepreneur. And finally, according to the agreements made in the contract, the bank will transfer the profit/loss resulting from the investment project to the resource supplier (depositors). Through offering these services, the bank will proceed to gain income, as a proportion of the profit of the investment project.

In Rastin Profit and Loss Sharing (PLS) Banking, the bank is a unit that on behalf of the depositor, will allocate his/her deposit resources to the applicants of financial resources, and based on the specific contracts, the obtained profit/loss will be divided among the depositor, the bank, and the entrepreneur. The contracts made by the bank with each of the parties can be on the basis of a fixed fee, or profit and loss sharing. An entrepreneur is a legal person, who has jointly shared his/her cash/non-cash paid-in capital with the depositor's partnership share, based on a specific contract and through the bank's intermediation, in order to initiate a joint venture investment. The trustee is a unit, which is responsible for supervising the Rastin Profit and Loss Sharing (PLS) process on behalf of the bank, for good implementation of the project by entrepreneur, reviewing the financial

\footnotetext{
${ }^{8}$ Smith, Adam (1974). The Wealth of Nations. Penguin.

${ }^{9}$ Hemant, Shah (20I I). The Production of Modernization: Daniel Lerner, Mass Media, and the Passing of Traditional Society. Philadelphia: Temple UP.

${ }^{\text {I0 }}$ Dobbin, Frank (1994). Cultural Models of Organization: The Social Construction of Rational Organizing Principles. Oxford: Basil Blackwell. pp. II7-I4I.

${ }^{\text {II }}$ Daft, Richard L. (2015) Organization Theory and Design I2 ${ }^{\text {th }}$ Edition, South-Western College Publisher.

${ }^{\text {I2 }}$ Daft, Richard L. (20I5) Organization Theory and Design I2 ${ }^{\text {th }}$ Edition, South-Western College Publisher.
} 
statements, and controlling the executive operations against the pre-announced plans and schedules (cited in the project proposal), the resource allocation method, and the optimal allocation of resources.

The depositor will become fully acquainted with different participation products, investment rules and regulations, and cancellation terms through visiting the information portal of the Rastin Certificate Market ${ }^{13}$, or by visiting one of the branches executing the Rastin Profit and Loss Sharing (PLS) Banking and consulting the respective expert at the information desk. Consequently, s/he can select one of the triple participation products. After signing and registering the contract, the system will automatically issue the Rastin Certificate with the depositor's details, in accordance with the customer's selected product. At the end of the participation period (for the two products of participation in single/multiple projects) or at the end of the year (for the product of participation in the profit and loss of the bank/branch), the accounting/auditing unit, by collecting the respective information about the profit/loss of the project(s) or the branch, will compute and pay the profit/loss, according to the participation duration and amount.

The entrepreneur will submit his/her project proposal for the implementation of the project to the bank through the PLS branch. Then, while informing the customer about the participation rules and regulations through the information portal of Rastin Certificate Market, or through the information desk in the branch executing the Rastin Profit and Loss Sharing (PLS) Banking, the fee related to the project proposal presentation will be taken from the customer (according to the respective instruction) and also, the information related to the proposed project (project proposal), including economic, technical, and financial justifications of the project, and other related data, will be received from the entrepreneur.

The assessment unit will assess the entrepreneur based on his/her records (if available) according to the related instructions. If the technical capability and competence of the entrepreneur are proved, the project proposal will go for an assessment. In the case that the project assessments result is positive, the project assessment unit will specify the type and amount of guarantees, collaterals, and paid-in capital of the entrepreneur, and inform the entrepreneur accordingly. After signing the contract, the required and approved resources will be provided to the entrepreneur in the framework of a partnership contract. In addition, according to the related instructions, all the documentation shall be submitted by the entrepreneur to the trustee, including the documents related to budgeting, scheduling, required resources, resource allocation method, project implementation process, phasing, quality control, reporting methods, project completion, and delivery. The supervision reports on the project implementation process, and the entrepreneur's performance quality shall be submitted to the bank's accounting/auditing unit at the pre-determined intervals. It is clear that the trustee's reports will be considered as the basis for the future payments of the bank to the entrepreneur. At the end of the project and according to the related instructions and formulas, the profit/loss value of the project, as well as the bank's fee will be calculated by the software of the accounting/auditing unit. The share of the entrepreneur and the depositor will be determined and paid to them. If there were a report/minute for delaying the project by the trustee, the delay duration and the loss value resulting from the delay will be determined and calculated and would burden to the entrepreneur according to the respective instructions. ${ }^{I 4}$

In order to implement Rastin Profit and Loss Sharing Banking, it can be done through establishing a company entity for this type of banking, or by defining or founding a new branch; we can start the Rastin Profit and Loss Sharing Banking. For the latter, the activities of Rastin Profit and Loss Sharing Banking will proceed in parallel with the other activities of the conventional branch. However, from a legal perspective and in compliance with the newly founded financial operations, all the financial, accounting, organizational, and operations must be distinct.

\section{Organizational Rules of the Rastin PLS Banking}

Mintzberg ${ }^{15}$ specifies that every organization has to have the five parts of technical core (people who do the necessary work), top management (provides direction, strategy, goals and policies for the entire organization), administrative support (for smooth operation and upkeep of the organization), middle management (for implementation and coordination on department level), and technical support ( $\mathrm{R} \& \mathrm{D}$, marketing research) as organizational configuration.

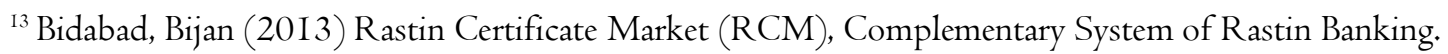

http://www.bidabad.com/doc/rastin-bank-rcm-en.pdf

${ }^{14}$ Bidabad, Bijan (2013) Rastin Profit and Loss Sharing (PLS) Base System. Journal of Islamic Economics, Banking and Finance, pp. 32-57,

Vol. 9 No. 4, Oct - Dec.

http://ibtra.com/pdf/journal/v9_n4_article2.pdf
}

${ }^{15}$ Mintzberg, H. (1992). Structure in fives: Designing effective organizations. Upper Saddle River, NJ: Prentice Hall. Mintzberg, H. (2009). Tracking strategies: Toward a general theory of strategy formation. New York, NY: Oxford University Press. 
Considering the concepts of Rastin Profit and Loss Sharing (PLS) Banking, the related processes, the codified criteria, and instructions for the implementation of this banking method, the specified tasks of the bank, the depositor, and entrepreneur, the required organization is as follows. In order to accelerate the process of implementation, the policy-making and executive units will work under the direct supervision of the supervising member of the board of directors. Moreover, in order to expedite the decision-making process, a strategic committee of Rastin Profit and Loss Sharing Banking and an expert committee for interpretation of the participation rules and processes will be formed so that given the description of the pre-determined duties, the project can be appropriately implemented and institutionalized.

Rastin Profit and Loss Sharing (PLS) Banking is composed of a "strategic committee of Rastin PLS banking", an "expert committee for interpretation of the participation rules and processes" and the bank's "PLS office". The members of the strategic committee of Rastin PLS banking are the supervising member of the bank's board of directors as committee chairman, an experienced scientific and executive advisor in the field of Rastin PLS banking as independent advisor, heads of the bank's PLS, legal, credits-loans, project assessment, funds allocation supervision, organization and procedures, research and planning offices; which the latter one will be the committee's secretary, and head of a selective PLS branch. If in any bank, some of the abovementioned offices do not exist, based on the recognition of the supervising member of the bank's board of directors, the heads of some offices with equivalent responsibilities will be replaced and will participate in the meetings.

The duties of this committee of Rastin PLS banking are expounded as making policies, approving the objectives, policies and instructions proposed by the expert committee for interpretation of the participation rules and processes, and supporting the creation of appropriate structures for the activities of the related professional and executive units, supervising on the correct implementation of the operational plans, in line with the objectives of Rastin PLS Banking and according to the Rastin Banking Act $^{16}$ and its executive bylaw ${ }^{17}$, coordinating the expert committee for interpretation of the participation rules and processes and the respective professional and executive units, pursuing and obtaining the required permits and approvals from the authorities outside the bank, in order to optimally implement Rastin PLS Banking. and coordinating the involved parties in Rastin PLS Banking and the related authorities outside the bank, and if necessary, outside the country.

The members of the expert committee for interpretation of the participation rules and processes are the head of the bank's PLS office as committee chairman, and an experienced scientific and executive advisor in the field of Rastin PLS Banking as independent advisor, and a legal professional as well as project assessment, credit-loan, funds allocation supervision, organizational studies, and planning expert professionals which the latter will be the committee's secretary. The professionals and representatives of other professional and executive units will attend the expert committee based on the subject if required. In order to protect, maintain, and develop the achievements of Rastin PLS Banking, the members of the expert committee must be properly experienced and knowledgeable in the field of Rastin PLS Banking.

The duties of the expert committee for interpretation of the participation rules and processes of Rastin PLS Banking are to conduct continuous studies on the latest changes and also, on the proposed improvements in Rastin PLS Banking inside and outside the country. Reviewing the reports prepared and submitted by the concerned professional and executive units, which need to be studied by the expert committee and also reviewing and revising the codified processes and instructions as well as the required organization and personnel, based on the proposed suggestions received from the respective units of the PLS office or based on the opinions of the committee members, and according to the results of the conducted surveys to ensure the consistent and optimal implementation of the project are other duties of this committee as well.

Under the direct supervision of the supervising member of the bank's board of directors, the PLS office is responsible for accomplishing the activities and affairs associated with the management of the Rastin PLS banking process, including announcements, equipment and allocation of the project resources, assessment, supervision, Rastin Certificate Market, and the required coordination among depositor, entrepreneur, trustee, the assessor, etc. The PLS office has the following units of legal, assessment, accounting/auditing, financial engineering, trustee, dispute resolution units and also office bureau and other necessary bureaus.

\footnotetext{
${ }^{16}$ Bidabad, Bijan; Azarang Amirostovar, Saeid Abdollahi, Mahmoud Allahyarifard, Eskandar Pordel, Maryam Heidari, Alireza Shafiei, Mohammad Ali Pourbehrouz. (20I2) Draft of Rastin Banking Bill, Bank Melli Iran.

http://www.bidabad.com/doc/rastin-banking-bill.pdf

${ }^{17}$ Bidabad, Bijan, Azarang Amirostovar, Saeid Abdollahi, Mahmoud Allahyarifard, Eskandar Pordel, Maryam Heidari, Alireza Shafiei, Mohammad Ali Pourbehrouz. (2012) Draft of Rastin Banking Executive Regulation, Bank Melli Iran.

http://www.bidabad.com/doc/rastin-banking-regulation.pdf
} 


\section{Legal Unit}

The legal unit is composed of knowledgeable legal experts (experienced in the field of Rastin PLS Banking), insurance expert, and the other necessary official personnel. The legal unit shall be composed of the bank's legal experts, who have at least a bachelor degree in judicial law, with at least 3 years of experience in the intended field of study, and insurance professional who has at least a bachelor degree in the field of insurance, with at least 3 years of experience in the intended field of study. The accreditation body for the legal and insurance experts will be the bank's claims and legal departments. With respect to the international and professional contracts, PLS office can employ legal and insurance consulting services outside the bank, whether domestic or foreign. Selection of the experts shall be made by observing the provisions of the bylaw. Moreover, legal unit personnel shall necessarily pass the training courses of Rastin PLS Banking at the required level. The educational level of the mentioned courses will be determined by the PLS office.

The duties of the legal unit are to prepare the minute of the contracts based on the subject of the proposed project, and altering, and modifying the minute of the insurance contracts, in relation to the proposed project and in accordance with the Rastin Banking Act and its executive bylaw. Performing legal supervision on the arrangement and conclusion of all the contracts, which are made towards implementing Rastin PLS Banking, and preparing, arranging and concluding the required contracts with the institutions outside the bank, including legal, research, consulting, executive, and other institutions (whether domestic or foreign) and offering legal consultation to PLS office, its affiliated units, and the bank's PLS branches are the other duties of the legal unit. It is also responsible for attending the arbitration sessions, and performing legal and judicial affairs, related to the cases that are held in judicial authorities, and lodging claim including civil and criminal lawsuits in any qualified authority (including judicial and non-judicial), whether inside or outside the country, and to codify general framework for civil and criminal claims, and collecting debts through registering and referring them to the claims and legal department of the bank and the affiliated units. Commenting and legal interpretation of Rastin Banking Act and its bylaw is a duty of legal unit as well.

\section{Assessment Unit}

Assessment unit is composed of economic, technical-engineering, foreign exchange, and financial experts, under the title of assessors, as well as the other necessary personnel. The duties of the assessment unit are to study and professional assessment of the project proposals, through primary and detailed assessments stages from economic, technical, engineering, and financial perspectives, and codifying a framework for supervising the project by the assessment unit experts (assessors), or if necessary, by the qualified professional assessment institutions outside the bank. It also studies the accuracy and validity of the documents and the information presented by the entrepreneur in the project proposal and its attachments and investigates the competence, qualification, and capabilities of the entrepreneurs, according to the records, proposal, and documents presented, based on the provisions of this Rastin Banking bylaw, by employing the conventional criteria in order to manage and diminish the risks of participation in investments. Obtaining the information, related to the indicators of each industry and the price list of the Management and Planning Organization and other similar credible authorities, for the purpose of the economic, financial, and technical assessment of the projects, according to the related economic, financial, and technical indicators, and also obtaining financial and credit information and the current status of the entrepreneur's commitments and debts in domestic and foreign currencies (inside and outside the country), through the qualified authorities and classifying the entrepreneurs; if needed, using the services of the other qualified professional institutions outside the bank for classifying the entrepreneurs are the duties of assessment unit. Assessment unit, if necessary, can oblige the parties to the Rastin Profit and Loss Sharing (PLS) contracts, both in the base system and the subsystems, to observe the necessary provisions of different chapters and articles of Rastin Banking bylaw, in addition to their particular obligations as well as determining and announcing the type and the amount of the collaterals, guarantees, and paid-in capital required from the entrepreneur, based on the bylaw's provisions and the other related regulations.

\section{Accounting/Auditing Unit}

Accounting/auditing unit is composed of financial experts, accountants, auditors, and other necessary personnel. The personnel of this must have necessarily passed the training courses of Rastin PLS Banking at the required level. The educational level of the mentioned courses will be determined by the bank's PLS office.

The duties of the accounting/auditing unit include auditing the non-cash collaterals, guarantees, and paid-in capital of the entrepreneur, valuing and appraising the assets and the project, and studying the information file of the customer, reviewing the newly obtained data, or changes in the past data, receiving and reviewing the supervision reports on the project implementation process and the entrepreneur's performance quality, as well as receiving the reports and process-verbal of probable suspensions of the project and related reasons, and calculating the bank's fee, the entrepreneur's wage, and the profit and loss shares of the 
entrepreneur and the depositor according to the bylaw's provisions, and calculating the effects of price alterations on income and cost flows of the projects, at the required times and based on the provisions of the bylaw, and assessing the cost and income effects resulting from probable delays, suspensions, and changes in the project scheduling.

\section{Financial Engineering Unit}

The financial engineering unit is composed of financial engineering, risk, and information and communication technology experts, as well as the other necessary personnel. The personnel of this unit must have necessarily passed the training courses of Rastin PLS Banking at the required level determined by the PLS office.

The duties of the financial engineering unit are to manage Rastin Certificate Market from different information and communication technology and financial engineering perspectives, to disclose the entrepreneur's information, according to the provisions of Rastin Banking bylaw about information disclosure in the bank's Rastin Certificate Market system, as well as to define and manage Rastin Certificates baskets through the classification of products, to maximize the returns and minimize the risks, and also, determining the weight of each certificate in the Rastin Certificates basket according to the risk and return rates of the products. Analyzing the external environment, identifying the economic sectors, and using the economic sector indices and the financial indicators of the stock market for the historical analyses of the risk of economic activities, predicting and estimating the risk and the return of each of the participation products, Rastin Certificates, and Rastin Certificates basket. The financial engineering unit is responsible to present the required reports and information to elaborate the subject to the expert committee for interpretation of the rules and processes of Rastin PLS Banking, and to manage the transactions of the bank's Rastin Certificate Market with the following activities of: codifying the bank's strategy in the Rastin Certificate Market, including market-making transactions, brokerage, and arbitrage; managing the bank's resources, allocated to the Rastin Certificate transactions towards increasing the returns of the resources; managing and optimizing the bank's Rastin Certificates baskets; collecting the information and analyzing the short- and long-term status of the economic and financial markets of the country as well as the international economic conditions and financial markets; managing the credit, operational, liquidity, and market risks, associated with the Rastin PLS Banking products and Rastin Certificates; collecting and analyzing the information, related to the transactions of Rastin Certificates and Rastin Certificates baskets; presenting the fundamental and technical analyses of the Rastin Certificates and Rastin Certificate baskets, including the current status of the industry, the project, and the market, by means of the conventional scientific techniques and methods; issuing the necessary permits and announcing the daily buying/selling rate of Rastin Certificates and Rastin Certificates baskets to the respective units; and preparing management reports and statistical analyses.

The financial engineering unit is obliged to monitor the Rastin Certificate Market constantly and in case of observing an unusual activity, in coordination with the bank's PLS office and in accordance with the codified instructions derived from the stock market and the other related regulations, shall temporarily halt the sales of Rastin Certificates in order to relieve the market pressure. It will also monitor the sales, resulting from unusual activities in the market and if no justification was found for the unusual activities in the market, in case necessary, it could request the trustee unit to review and control some specific projects in order to find the roots of the problem. If the unusual activity is due to some rumors, report or publication of important information that has led to the unusual activity, the financial engineering unit through the PLS office will request the entrepreneur to do the appropriate corrective measures. The financial engineering unit, with the approval of the bank's PLS office, can delay the trading of the Rastin Certificates of the entrepreneur (or his/her projects), until accomplishing the necessary measures.

\section{Trustee Unit}

The trustee unit is composed of financial, technical, and engineering experts under the title of "trustee" as well as the other necessary personnel. The duties of the trustee unit include: receiving the documents and evidence of the assessed and accepted project proposal by the assessment unit about the entrepreneur and the project; and reviewing all documents and permissions, and controlling the budget, schedule, required resources/expenditure, and the implementation process from the beginning to the completion and delivery of the project. Trustee unit determines the time and content of the periodic reports of the entrepren eur; and specifies the control headings and the required information, this should be presented in the special forms of reports, minutes, and agendas, before the beginning of the project and according to the requirements of each project. Designing the report forms, minutes, and their contents with suggestion and coordination of the assessment unit; and reviewing and approving the periodic reports, minutes, and guidelines prepared by the entrepreneur; and receiving and reviewing the financial and accounting documents (including cost and income related documents) at all stages of the project; as well as supervising on good implementation of the project, controlling the executive operations compared to the schedules and predictions of the proposal, 
and monitoring the allocation of resources and their optimal expenses (these investigations should be carried out based on the activity type of the project and according to the statements presented by the entrepreneur, on a monthly basis, or if necessary, in shorter periods) are the duties of the trustee unit. This unit is also responsible for determining, calculating, and controlling the key indicators in the implementation of the project in accordance with the executive and financial aspects, and preparing the required reports by considering these indicators, with emphasis on cost, income, time, and quality of the implementation process.

The trustee unit is responsible for managing and commenting on the fund usage, accounts keeping, and financial statements of the project; presenting the report, including the supervision details of the implementation operation and the entrepreneur's quality of work, to the bank's PLS office to be referred to the accounting/auditing unit; providing report about the minute of the probable suspensions of the project, along with the documents and evidence related to the bank's PLS office to be referred to the accounting/auditing unit; reviewing and approving the expenditures made by the entrepreneur, at every stage of the physical development of the project; preparing the necessary arrangements for supplying and paying the requested resources of the entrepreneur at various stages; confirming the supply of cash resources (funds), required by the entrepreneur, as pre-paid, based on the type of the project, and according to the recognition of the bank's PLS office, the settlement of advance payments, whether at once or at stages, the legal costs of the project, including tax, insurance, and other statutory deductions acceptable by the bank; studying the documents, provided by the entrepreneur, about the insufficiency of the previously supplied resources, and approving and issuing permission of new Rastin Certificates; recognizing and examining the type and duration of delays, resulting from the entrepreneur's operations; final investigation of the project to settle the accounts with the entrepreneur, after the definite delivery of the project; presenting the evaluation report and the entrepreneur classification report to the fund bureau, to be inserted in the entrepreneurs' records; all in accordance with the provisions and instruction of the Rastin Banking bylaw. The supervision group of the trustee unit is composed of two distinct parts of engineering and financial groups.

\section{Dispute Resolution Committee}

The members of the dispute resolution committee of the PLS office are the head of the PLS office as chairman, an experienced independent advisor in the field of Rastin PLS Banking, heads of the legal unit, the assessment unit and the trustee unit of the PLS office and the head of the bank's inspection office. The trustee and assessor of the project and the entrepreneur engaged are other members of the committee. If needed, according to the disputed subject, the experts and representatives of the other technical and executive units will participate in the dispute resolution committee according to the committee's decision. The committee's decision will be valid and binding according to the majority vote of the first five persons. In the case of disagreement of the entrepreneur with the decision of the dispute resolution committee, $\mathrm{s} / \mathrm{he}$ can pursue the dispute through arbitration, according to the provisions of the bylaw about arbitration. If the results of the arbitration confirm the decision of the dispute resolution committee, all the damages resulting from this delay in the settlement will be burdened on the entrepreneur according to the instructions about changes in the schedule. These costs will be deducted from her/his yield share, guarantees, and collaterals, and after deducting the bank's yield share, the remained amount will be paid to the depositor.

The duties of the dispute resolution committee of PLS office are to review and make a decision on the dispute between the entrepreneur and the trustee, and also scrutiny and interpreting the contract, Rastin Banking Act, and the executive bylaw of Rastin Banking in relation to the projects.

\section{Rastin PLS Branch}

Rastin PLS branches are selected by PLS office and are responsible for the implementation of the project in accordance with the provisions of the bylaw and under the supervision of the supervisory organ on the branches. These branches, for offering their conventional banking services, in addition to their organizational and operational structure similar to the other branches, must have some bureaus such as information and partnership counseling services bureau. Moreover, their fund bureaus, alongside the normal duties of all other fund bureaus, must also perform the particular duties associated with Rastin PLS Banking services.

The personnel of the information and partnership counseling services bureau and the fund office in Rastin PLS Banking branches must have necessarily passed the training courses of Rastin PLS Banking at the required level. The educational level of the mentioned courses will be determined by the PLS office.

The duties of the information and partnership counseling services bureau are to obtain the information, related to different PLS banking products, the terms and conditions of the depositor and entrepreneur, and the depositing procedure, as well as the requests, documents, and documentation of entrepreneurs, filling out the forms related to projects and identification codes, and recording the completed forms in the computer database of the bank. Providing information and PLS banking consulting services to the customers (including depositors, entrepreneur, etc.), for the products and partnership conditions in the Rast in 
PLS branches, and receiving the deposit or redeposit requests, completing the forms related to identification codes, and recording them in the computer database of the bank are other duties of this bureau.

The fund bureau in the Rastin PLS branch, in addition to its conventional activities similar to the other fund bureaus, in accordance with the provisions of the bylaw and the respective regulations, is also responsible for the following duties under the supervision of the branch authority. Receiving the completed forms, related to the purchase and sale of Rastin Certificates, deposit fund, paid-in capital, and the cash partnership shares of customers (depositor and entrepreneur), and paying the settled amounts of Rastin Certificates. Issuing Rastin Certificates and the order to pay the amount of the traded Rastin Certificates, recording the information and issuing specific identification code for every customer, receiving and recording the information, related to customers and products and retrieving the information, related to the identification code of each customer, performing Rastin Certificate transactions (buying, selling, and transferring), under the provisions of the bylaw and making final settlement with the last owner of the Rastin Certificates, in collaboration with the other relevant units (including the auditing unit of PLS office) are the other duties of the fund bureau.

\section{Personnel Qualifications}

All the personnel of the PLS office is appointed after participating in the training courses, passing the related exam, and being interviewed by the qualified authorities. That is all the personnel of the PLS office at different levels of expertise, and also, the heads and deputies of different units must have passed the introductory, intermediate, and advanced training courses of Rastin PLS Banking. The members of the Rastin PLS committees as well as the "strategic committee of Rastin PLS banking", and "expert committee for interpretation of the participation rules and processes", who were responsible for drafting this Rastin banking bylaw, are not obliged to take these training courses.

Promoting the position of the assessor, trustee, legal expert, auditor, accountant, and financial engineer is in accordance with the terms and conditions of the bank. In order to obtain a position in the PLS office, the appointed person must meet the minimum requirements in the following table $\mathrm{I}$. (the units in the table are in years):

Table I. Minimum requirements for occupying staff in different departments (in years)

\begin{tabular}{|c|c|c|c|c|c|c|c|c|c|c|c|}
\hline Degree & & ache & & & Mast & & & Ph.I & & \multirow[b]{2}{*}{ Basic education } & \multirow[b]{2}{*}{ Notes } \\
\hline Title & 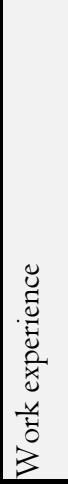 & 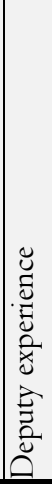 & 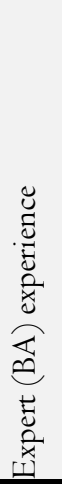 & 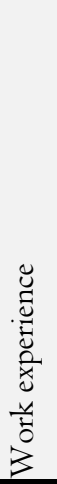 & 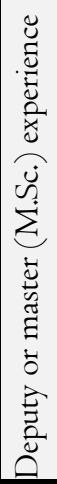 & 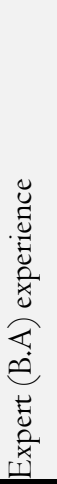 & 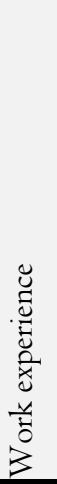 & 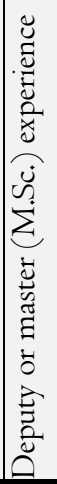 & 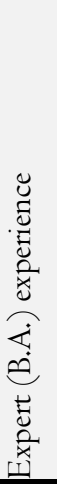 & & \\
\hline Head of PLS office & 20 & 2 & 5 & $\mathrm{I7}$ & $\mathrm{I}$ & - & $\mathrm{I} 5$ & $\mathrm{I}$ & - & & \\
\hline Deputy of PLS office & I5 & - & 10 & $\mathrm{I} 2$ & - & $\mathrm{IO}$ & $\mathrm{IO}$ & - & $\mathrm{IO}$ & & \\
\hline \multicolumn{12}{|l|}{ Head of the units: } \\
\hline Trustee & 15 & - & 10 & 12 & - & 10 & $\mathrm{IO}$ & - & $\overline{\mathrm{IO}}$ & \multirow{2}{*}{$\begin{array}{l}\text { Technical, } \\
\text { Economics, } \\
\text { Financial, } \\
\text { Foreign } \\
\text { exchange }\end{array}$} & \multirow[b]{2}{*}{$\begin{array}{l}\text { Credit work } \\
\text { experience }\end{array}$} \\
\hline Assessor & I5 & - & I0 & $\mathrm{I} 2$ & - & 10 & 10 & - & I0 & & \\
\hline
\end{tabular}




\begin{tabular}{|c|c|c|c|c|c|c|c|c|c|c|c|}
\hline Legal & I5 & - & IO & $\mathrm{I} 2$ & - & IO & IO & - & IO & Legal & $\begin{array}{l}\text { Legal work } \\
\text { experience }\end{array}$ \\
\hline Accounting/Auditing & 15 & - & 10 & 12 & - & 10 & 10 & - & IO & $\begin{array}{l}\text { Finance, } \\
\text { Accounting }\end{array}$ & $\begin{array}{l}\text { Credit and } \\
\text { financial work } \\
\text { experience }\end{array}$ \\
\hline Financial engineering & \multicolumn{3}{|c|}{$\begin{array}{l}\text { Cannot be } \\
\text { employed }\end{array}$} & $\mathrm{I} 2$ & - & I0 & IO & - & IO & $\begin{array}{l}\text { Financial } \\
\text { engineering, } \\
\text { Statistics, } \\
\text { Economics }\end{array}$ & $\begin{array}{l}\text { Financial and } \\
\text { other related } \\
\text { work experience }\end{array}$ \\
\hline \multicolumn{12}{|l|}{ Experts: } \\
\hline Trustee & 10 & - & 8 & 8 & $\overline{-}$ & 5 & 7 & - & 5 & \multirow{6}{*}{$\begin{array}{l}\text { Financial } \\
\text { engineering, } \\
\text { Mathematic, } \\
\text { Statistics, } \\
\text { Economics }\end{array}$} & \multirow{6}{*}{$\begin{array}{l}\text { Interview and } \\
\text { exam }\end{array}$} \\
\hline Assessor & $\mathrm{IO}$ & - & 8 & 8 & - & 5 & 7 & - & 5 & & \\
\hline Legal & 10 & - & 8 & 8 & - & 5 & 7 & - & 5 & & \\
\hline Auditing & IO & - & 8 & 8 & - & 5 & 7 & - & 5 & & \\
\hline Accounting & 10 & - & 8 & 8 & - & 5 & 7 & - & 5 & & \\
\hline Financial engineering & $\mathrm{IO}$ & - & 8 & 8 & - & 5 & 7 & - & 5 & & \\
\hline
\end{tabular}

In order to appropriate implementation of Rastin Banking and preserve and protect the rights of depositors, entrepreneurs, and those who see the bank as their trustee, all personnel at all levels of management and lines are required to implement the Rastin banking regulations and bylaws accurately and avoid any breach of rights. The managers, experts, and other employees, at different levels, through observing the provisions of the Rastin Banking Act and its executive bylaw, are obliged to obey the orders of their superiors in the boundaries of the rules and regulations. If a manager, an expert, or any other employee, at different levels, recognizes the order/command of his/her superior contrary to the laws and regulations, s/he is obliged to notify the superior in writing about the order incompatibility with the laws and regulations. If, after this notification, the superior still confirmed his/her order in writing, s/he will be obliged to implement the issued order and then, declare the matter to the bank's inspection office. Also, the superior is obliged to provide his/her final and explicit idea about the issue of this article in writing to the subordinate, maximum within 4 working days.

\section{Organizational Culture and Ethics}

In organizations, relationships should be based on the trust, mutual understandings, and shared norms and values to enable inside and outside people of the organization to cooperate and coordinate their activities to achieve the goals. Culture as the set of values, norms, understandings, and beliefs is shared by personnel and is taught to new employees. To institutionalize social capital and culture and ethics in an organization, many concrete and elegant provisions should be established. It is one of the hardest parts of designing an organization structure, and it cannot be definitely defined, because its core elements come from different human beings' characters. To make necessary provisions for attaining this goal, exact instructions including professional ethics, audit, inspection, control, monitoring and preservation (vigilance) were prepared for Rastin Profit and Loss Sharing (PLS) Banking to establish operational ethical banking. ${ }^{18}$

In this regard, the managers and employees are obliged to refrain from forcing the subordinates to do anything contrary to the rules and regulations, or from abusing their own professional and administrative position, refrain from misusing the professional position, facilities, and properties available to them, for delaying the proposal implementation, or not carrying out the proposal, or implementing an unapproved proposal; Avoid any discrimination among the depositors, entrepreneurs, trustees, assessors, etc. who are in identical circumstances; disclose or avoid disclosing information, against the information disclosure regulations; avoid

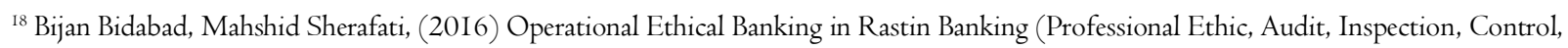
Monitoring and Preservation). International Journal of Law and Management, Vol: 58, Iss:4, pp. 4I6-443.

http://dx.doi.org/I0.II08/IJLMA-07-2015-0037 
presenting false certificates, approvals, or reports, the confiscation, concealment, inspection, or opening of the sealed parcels, or their obliteration without the necessary legal formalities, demanding any money, property, or privilege from the depositors, entrepreneurs, etc. apart from the Rastin Banking Act and its executive bylaw, under any condition, annoying, harassing, insulting, slandering, and defaming customers and employees, counterfeiting, distorting, falsifying the documents, records, and evidence, and avoid deceiving/facilitating the commitment of such violations and deliberate use of such documents, and to avoid embezzlement, conspiracy, extortion, bribery and other financial and administrative corruptions, and Avoid submitting the documents and information to those individuals, who are not entitled to possess them, and submit the documents and information to individuals, who are entitled to have them, and refrain from any failure/negligence in the performance of the assigned duties.

They are all obliged to act and behave in accordance with the administrative and professional norms, and carry out the assigned tasks, with no delay, and comply with the respective laws and regulations, along with preserving the individuals' properties, documents, funds and confidential information, and should prevent any kind of damage to the individuals' properties; and select and appoint the experts and employees (including the assessor, trustee, and auditor), who are legally qualified.

All managers, experts and other employees of the bank, and the bank's colleagues such as assessors, trustees, and auditors, at different levels of Rastin banking, are obliged to refrain from accepting any fund or property, which is delivered to them directly/indirectly, with/without mediate, for free, or through granting a privilege, or providing a payment slip, or surrendering a property, or conducting a transaction with unusual market fee, out of the concluded contracts in the framework of Rastin Banking rules and regulations.

\section{References}

Bidabad, Bijan; Azarang Amirostovar, Saeid Abdollahi, Mahmoud Allahyarifard, Eskandar Pordel, Maryam Heidari, Alireza Shafiei, Mohammad Ali Pourbehrouz. (2012) Draft of Rastin Banking Bill, Bank Melli Iran.

http://www.bidabad.com/doc/rastin-banking-bill.pdf

Bidabad, Bijan, Azarang Amirostovar, Saeid Abdollahi, Mahmoud Allahyarifard, Eskandar Pordel, Maryam Heidari, Alireza Shafiei, Mohammad Ali Pourbehrouz. (2012) Draft of Rastin Banking Executive Regulation, Bank Melli Iran.

http://www.bidabad.com/doc/rastin-banking-regulation.pdf

Bidabad, Bijan, Rastin Certificate Market (RCM), Complementary System of Rastin Banking, 2013. International Journal of Islamic Business \& Management, 3(I), 35-43, 2019.

https://www.cribfb.com/journal/index.php/ijibm/article/view/260

http://www.bidabad.com/doc/rastin-bank-rcm-en.pdf

Bidabad, Bijan, Rastin Profit and Loss Sharing (PLS) Base System. Journal of Islamic Economics, Banking and Finance, pp. 3257, Vol. 9 No. 4, Oct - Dec 2013.

http://ibtra.com/pdf/journal/v9_n4_article2.pdf

http://www.bidabad.com/doc/pls-base-en.pdf

Bidabad, Bijan, Mortgage Securitization System (MSS), A Complementary System of Rastin Banking. International Journal of Law and Management (IJLMA), Vol. 59 Issue: 6, pp.778-783, 2017.

https://doi.org/I0.I 108/IJLMA-05-2016-0045

http://www.bidabad.com/doc/mss-paper-en.pdf

Bidabad, Bijan, Money Laundering Detection System (MLD), A Complementary System of Rastin Banking, Journal of Money Laundering Control, Vol. 20 Issue: 4, pp. 354-366, 2017.

https://doi.org/I0.I I08/JMLC-04-2016-0016

http://www.bidabad.com/doc/mld-paper-en.pdf

Bidabad, Bijan, Mahmoud Allahyarifard, Interbank Withdrawal Protocol (IWP), Complementary System of Rastin Banking 2013. International Journal of Islamic Business \& Management, 3(I), 30-34, 2019.

https://www.cribfb.com/journal/index.php/ijibm/article/view/259

http://www.bidabad.com/doc/iwp-paper-en.pdf 
Bidabad, Bijan, Mahshid Sherafati, Bank Information Disclosure, Financial Transparency and Corporate Governance in Rastin Banking, International Journal of Shari'ah and Corporate Governance Research, 2(I), I-I3, 2019.

https://www.cribfb.com/journal/index.php/ijscgr/article/view/257

http://www.bidabad.com/doc/shafafiyat-en.pdf

https://doi.org/I0.20193/ijscgr.v2iI.257

Bidabad, Bijan, Mahshid Sherafati, Financial Transparency, Governance and Public Disclosure for Entrepreneur (Financial Resource Receiver) in Rastin Banking System. Tehran, Iran, 2015.

http://www.bidabad.com/doc/transparency-entrepreneur-en.pdf

Bidabad, Bijan, Azarang Amirostovar, Mahshid Sherafati, Financial Transparency, Corporate Governance and Information Disclosure of the Entrepreneur's Corporation in Rastin Banking. International Journal of Law and Management (IJLMA), Vol:59, Iss:5, pp.636-65I, 2017. https://doi.org/IO.I I08/IJLMA-0I-2016-0003

Bidabad, Bijan, Saeid Abdollahi, Mahshid Sherafati, (2015) Proposed Regulations for Enforcement of Purports of Binding Banking Documents in Rastin Banking, Tehran.

http://www.bidabad.com/doc/rastin-bank-ejraye-asnad-en.pdf

Bidabad, Bijan, Saeid Abdollahi, Mahshid Sherafati, Enforcement of the Purports of Binding Banking Documents in Rastin Banking - Part I. International Journal of Law and Management (IJLMA), Vol:59, Iss:I, pp.52-65, 2017. https://doi.org/I0.I I08/IJLMA-07-20I5-004I

Bidabad, Bijan, Saeid Abdollahi, Mahshid Sherafati, Enforcement of the Purports of Binding Banking Documents in Rastin Banking - Part II. International Journal of Law and Management (IJLMA), Vol:59, Iss:2, pp.I78-I9I, 2017. https://doi.org/IO.I I08/IJLMA-IO-20I5-0055

Bidabad, Bijan, Mahshid Sherafati, Sustainable Financing and Anti-Squandering Measures in Rastin Banking. International Journal of Law and Management (IJLMA), Vol. 59 Issue: 6, pp.939-949, 2017.

https://doi.org/IO.I I08/IJLMA-04-2016-0037

http://www.bidabad.com/doc/esraf-bank-resource-en.pdf

Bidabad, Bijan, Serial Commitments Clearance (SCC) in Rastin Banking, International Journal of Law and Management (IJLMA), Vol. 57, Iss: 6, 20I5, pp. 600-609. http://dx.doi.org/I0.I I08/IJLMA-02-2015-0007 http://www.bidabad.com/doc/scc-paper-en.pdf

Bidabad, Bijan, Mahshid Sherafati, Operational Ethical Banking in Rastin Banking (Professional Ethics, Auditing, Inspection, Control, Monitoring and Preservation). International Journal of Law and Management (IJLMA), Vol: 58, Iss: 4, 20I6, pp. 4 I6 - 443.

http://dx.doi.org/I0.I108/IJLMA-07-2015-0037

http://www.bidabad.com/doc/rastin-ethic-banking-en.pdf

Bidabad, Bijan, General Regulatory Framework in Rastin Profit and Loss Sharing Banking (Part I-Operational Context). Journal of Business and Finance in Emerging Markets, JBFEM, [S.1.], v. I, n. I, p. I I-26, May 20I8. ISSN 2580-5568. https://doi.org/I0.32770/jbfem.volI I I -26 http://www.bidabad.com/doc/rastin-regulatory-en-I.pdf

Bidabad, Bijan, General Regulatory Framework in Rastin Profit and Loss Sharing Banking (Part II-Legal Groundwork). Journal of Business and Finance in Emerging Markets, JBFEM, [S.1.], v. I, n. 2, p. I09-I26, Nov. 20I8. ISSN 2580-5568. https://doi.org/I0.32770/jbfem.volI I09-I26 http://www.bidabad.com/doc/rastin-regulatory-en-II.pdf

Bidabad, Bijan, General Regulatory Framework in Rastin Profit and Loss Sharing Banking (Part III-Auxiliary Provisions). Journal of Business and Finance in Emerging Markets, JBFEM, May 2019, Vol 2, No. I, pp. 5I -65. ISSN $2580-5568$. 
https://doi.org/I0.32770/jbfem.vol25I-66

http://www.bidabad.com/doc/rastin-regulatory-en-III.pdf

Bidabad, Bijan, Azarang Amirostovar, Saeid Abdollahi, Mahmoud Allahyarifard, Eskandar Pordel, Maryam Heidari, Alireza Shafiei, Mohammad Ali Pourbehrouz (2012), Draft of Rastin Banking Bill, Bank Melli Iran. http://www.bidabad.com/doc/rastin-banking-bill.pdf

Bidabad, Bijan, Azarang Amirostovar, Saeid Abdollahi, Mahmoud Allahyarifard, Eskandar Pordel, Maryam Heidari, Alireza Shafiei, Mohammad Ali Pourbehrouz (2012), Draft of Rastin Banking Executive Regulation, Bank Melli Iran.

http://www.bidabad.com/doc/rastin-banking-regulation.pdf

Daft, Richard L. (2015) Organization Theory and Design I2th Edition, South-Western College Publisher.

Dobbin, Frank (1994). Cultural Models of Organization: The Social Construction of Rational Organizing Principles. Oxford: Basil Blackwell. pp. II7-I4I.

Hemant, Shah (201 I). The Production of Modernization: Daniel Lerner, Mass Media, and the Passing of Traditional Society. Philadelphia: Temple UP.

Mintzberg, H. (1992). Structure in fives: Designing effective organizations. Upper Saddle River, NJ: Prentice Hall.

Mintzberg, H. (2009). Tracking strategies: Toward a general theory of strategy formation. New York, NY: Oxford University Press.

Smith, Adam (1974). The Wealth of Nations. Penguin.

Taylor, Frederick Winslow (I9II). The principles of scientific management. New York: Harper Brothers.

Weber, Max. Economy and Society: An Outline of Interpretive Sociology (2 Volume Set). University of California Press.

\section{Copyrights}

Copyright for this article is retained by the author(s), with first publication rights granted to the journal. This is an open-access article distributed under the terms and conditions of the Creative Commons Attribution license (http://creativecommons.org/licenses/by/4.0/). 